\title{
Rural Road Improvement and Farmland Circulation: The Production Cost Perspective
}

\author{
Zhaoxiang Wu \\ Family Business Center, Sun Yat-sen University, Guangzhou, China \\ Email: wuzhaoxiang1989@Gmail.com
}

How to cite this paper: $\mathrm{Wu}, \mathrm{Z} . \mathrm{X}$. (2018) Rural Road Improvement and Farmland Circulation: The Production Cost Perspective. American Journal of Industrial and Business Management, 8, 2061-2071. https://doi.org/10.4236/ajibm.2018.810136

Received: March 20, 2018

Accepted: September 5, 2018

Published: October 9, 2018

Copyright (C) 2018 by author and Scientific Research Publishing Inc. This work is licensed under the Creative Commons Attribution International License (CC BY 4.0).

http://creativecommons.org/licenses/by/4.0/

(c) (i) Open Access

\begin{abstract}
This paper comprehensively investigates the impact of rural road infrastructure improvement on farmland transfer from the perspective of agricultural production costs. Based on a theoretical analysis framework, this paper builds a theoretical model of supply and demand for the village farmland transfer and discusses the trend of the equilibrium point between supply and demand before and after the improvement of rural road infrastructures. This is taken as the starting point for the theoretical analysis to discuss the impact of the improvement of rural road infrastructures on village farmland transfer. According to the analysis, the corresponding research hypothesis is proposed. Moreover, by employing 2018 survey data on a village in the Anhui Province, the research conclusions are obtained. Specifically, the Tobit regression model analysis highlights that the increase in rural road infrastructures does have a significant impact on agricultural land transfer.
\end{abstract}

\section{Keywords}

Rural Road, Farmland Transfer, Village

\section{Introduction}

The land system and the effective allocation of land resources have a profound impact on economic development in China. With the acceleration of urbanization and the non-agricultural transfer of rural labor, the phenomenon of land abandonment and land idleness has become very common in vast rural areas [1]. This severely restricts farmers' income and agricultural production, thus representing the biggest barrier to China's agricultural modernization. The transfer of farmland contract management rights has become the optimal path to achieve large-scale agricultural management, which plays a great role in promoting agricultural modernization and enabling the effective allocation of land 
resources [2].

Existing research highlights that the farmer's decision to participate in a land transfer is closely related to the benefit and efficiency of the agricultural production and non-agricultural employment opportunities [3]. As the supply of rural labor continues to decrease, the opportunity cost of farming increases, and, thus, the supply of agricultural land theoretically increases. At the same time, agricultural subsidies, improved varieties, agricultural machinery, and socialized services have significantly reduced the cost of agricultural production, and the demand for circulation has also increased [4]. Moreover, the property rights system of agricultural land is well defined. However, at the end of 2017, while the country's farmland transfer scale reached 447 million mu, the transfer rate of agricultural land was only $33.3 \%{ }^{1}$. In addition, there are still vast regional differences. Compared with China's urbanization rate (56.1\%), the scale and turnover rate of farmland transfer need to be further improved. This shows that the turnover rate and circulation scale of agricultural land do not respond negatively under sufficient supply of agricultural land.

The factors affecting farmers' land transfer decisions have been largely discussed in the existing literature. However, the impact of the lack of infrastructure investments in rural areas and particularly, the lack of sufficient supply of road infrastructures, has not aroused enough attention. It is well known that, in the process of farmland transfer, the agricultural production costs of agrarian land renters are very high due to imperfect agricultural road infrastructures. While reducing the probability of renting agricultural land, lessors are less interested in signing a long-term lease contract due to the low rental price.

Therefore, this paper states that the lack of investment in rural road infrastructures has increased the uncertainty of land transfer to some extent. In the existing literature, the impact of rural road infrastructure investments has been studied from the perspectives of agricultural production costs reduction, increase of farmers' non-agricultural employment opportunities and income, as well as promotion of rural economic development [5]. This paper attempts to analyze the impact of rural road infrastructure inputs on farmland transfer from the perspective of agricultural production costs reduction.

\section{Theoretical Analysis and Research Hypothesis}

The rural road infrastructure considered in this paper refers to social products and services used to meet public needs for rural private goods in rural areas. Road infrastructure has the general characteristics of public goods, such as the indivisibility of utility, the non-competitiveness in consumption, and the non-exclusiveness of benefits. Besides, due to the vast rural areas and scattered farmer residence, it is impossible to provide road infrastructure on a large scale and then obtain high returns like the case in intensive urban supply. Therefore, the supply of rural road infrastructures is also characterized by a huge invest${ }^{1}$ Public data from the Ministry of Agriculture (http://www.tuliu.com/read-46231.html). 
ment level and low marginal cost.

From the perspective of the existing supply body of rural road infrastructures, the government, rural communities, and rural management subjects are essential forces. Among them, village-level organizations and rural operators have shouldered a large part of rural road investments, and the government's investment is also increasing [6]. However, compared with the same development stage in developed countries, the supply of rural roads in China is still insufficient [7]. The improvement of rural road infrastructures is also crucial for agricultural business entities (especially large professional households from the farmland inflow side), which are the main beneficiaries of the infrastructure." Also, please note that the terms "farmland inflow" and "farm outflow" (used later in this paragraph) are not very clear. If you meant lessors and lessees, respectively, please consider adding an explanation.. Due to the relatively large operating area, high agricultural income, and the relatively high levels of operation and management, the improvement of rural road infrastructures is required. However, many constraining factors in the development process (subject dislocation) make investing in rural road infrastructure unlikely [8]. Part-time farmers in the farmland outflow side derive a considerable proportion of income from non-agriculture activities, and their ultimate utility from improving rural road infrastructures is little or negative. Therefore, there is a general lack of motivation for improving rural road infrastructures.

Considering farmland transfer as a process of re-allocation of rural land resources, part-time farmers choose to rent out land only when the sum of the expected income from non-agricultural production of the land outflow and the land rent of the farmland outflow side exceeds the income from land cultivation; similarly, the farmland inflow side chooses to rent the land when the land management income exceeds the sum of the opportunity cost of cultivating and the land rent. Thus, the land transfer process can only occur when the above two conditions are simultaneously met. The increase in the production costs caused by imperfect rural road infrastructures causes land inflow parties to face uncertain business risks in the production and operation processes. At high costs, the land inflow side can only ensure the safety of operations by paying lower rent and reducing their demand for farmland. For the land outflow side, however, low rents lead to a reduction in the willingness to rent land out, resulting in a reduction in farmland supply. The development status of low turnover rate and low economic benefit characterizes the Chinese farmland transfer market under the joint action of both supply and demand. The specific logic analysis is shown in Figure 1.

\section{Measurement Model Design and Statistical Description of Variables}

\subsection{The Setting of the Measurement Model and the Description of the Main Variables}

This paper aims to explore the impact of rural road infrastructure improvements 


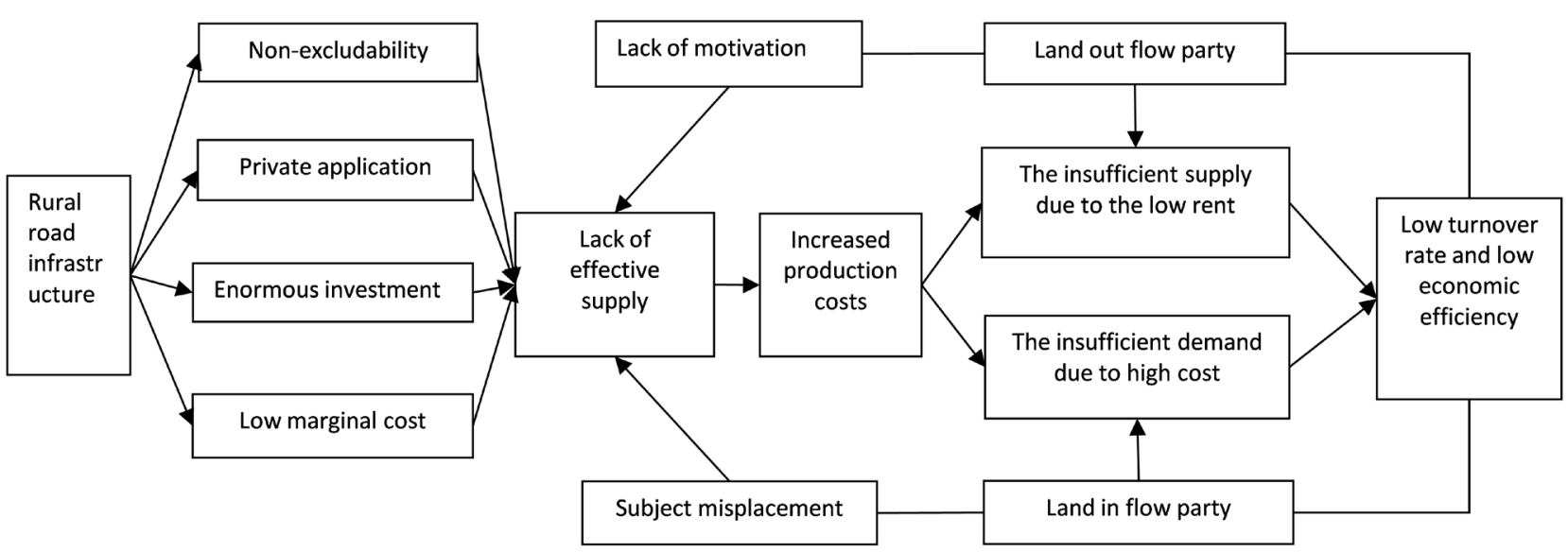

Figure 1. Logical analysis diagram of the impact of inadequate supply of rural road infrastructures on farmland transfer.

on farmland transfer. Since the measured index for the interpreted variable is the farmland transfer rate, and the value of this variable ranges between 0 and 1 , it is a "restricted explanatory variable." For a regression model with both ends truncated, the interpreted variables are compressed and merged. Even with quite complete data, there are inconsistencies in the estimation results using ordinary least squares. In this case, maximum likelihood estimation method is the most suitable choice ${ }^{2}$ [9]. Therefore, the setting of the econometric model in this study is based on the Tobit truncated regression model, which is suitable for restricted explanatory variables. The specific model form is as follows:

$$
\begin{gathered}
Y_{i}^{*}=\beta Z_{i}^{\prime}+\varepsilon_{i}, \quad \varepsilon_{i} \mid z_{i} \sim N\left(0, \sigma^{2}\right) \\
Y_{i}= \begin{cases}0 & Y_{i}^{*} \leq 0 \\
Y_{i}^{*} & 0 \leq Y_{i}^{*} \leq 1 \\
1 & Y_{i}^{*} \geq 1\end{cases}
\end{gathered}
$$

In Equation (1), $Y_{i}$ is the farmland transfer rate or land turnover rate of the sample village, while $Y_{i}^{*}$ is the potential variable corresponding to the restricted explanatory variable; $Z_{i}$ is the explanatory variable vector, including the intercept term; $\beta$ is the corresponding explanatory variable vector coefficient; and the subscript $i$ identifies the sample village in the research area. In terms of variables selection, the study assumes that the following variables may affect the village's farmland transfer rate based on the existing research results (see the literature review section) and the above theoretical analysis. The specific variable settings are as follows:

\subsubsection{Explained Variable}

Farmland transfer usually includes whether the village is characterized by farmland transfer and the corresponding transfer rate. The village outflows farmland refers to whether the farmland transfer behavior occurs in the sample village in

${ }^{2}$ Chen Qiang, Advanced Econometrics and Stata Application (Second Edition), Beijing: Higher Education Press, 2017(1): 238-243. 
the corresponding year between 2010 and 2016. The village farmland transfer rate measures the relative size of the transfer and is used as the explained variable.

\subsubsection{Explanatory Variable}

\section{1) Country road.}

Existing research indicates that farmers have the strongest demand and the lowest satisfaction with rural road and farmland water conservancy investments among the government's rural road infrastructure investments [10]. Given the lack of data on farmland water conservancy facilities in village surveys, whether villages have built village-to-village roads as well as their length is emphasized and regarded as one of the core variables for rural road infrastructure improvements in this study. In addition, various types of highways such as national and provincial highways play a role in connecting urban and rural areas in the process of agricultural development, which promotes the development of the urban and rural economy [11] and affects the willingness of farmers to participate in the transfer [12].

\section{2) Characteristics of the village farmland.}

The variables characterizing farmland include the rent of farmland in the villages, the per capita cultivated farmland area, and the type of cultivated land. The arable land type variable captures the impact of different types of farmland in the unobserved villages on the farmers' farmland transfer. The virtual variables for the three cultivated land types are: mountainous, hilly, and plain. Due to the different natural geographical environments, there are also large differences in the farming methods across regions. Especially for farmers in highly mountainous and hilly areas, complex terrain and narrow per capita arable land seriously restrict improvements toward mechanization of agriculture, and the characteristics of farmers' employment are also different [13]. According to previous studies, the smaller the per capita arable land area, the stronger the farmers' willingness to transfer agricultural land [14]. From the perspective of economic rationality, whether farmers are willing to transfer the contracted management rights of the agricultural land mainly depends on whether the roll-out user can obtain higher farmland transfer rents for a long time [15]. In order to prevent the rent factors of village farmland from having an endogenous impact on the circulation of farmland, the previous year rent level is used in the questionnaire design of rent factors.

\section{3) The characteristics of the agricultural production in villages.}

The characteristic variables of the agricultural production in villages mainly include the non-agricultural production status of village labor and the opportunity cost of village agricultural production. In the field research, we found that most farmers are in a part-time business, engaged in both agricultural production and out to work during the slack season. The opportunity cost of agricultural production has a greater impact on whether farmers are engaged in agricultural production for a long time. When the proportion of non-agricultural 
income to total household income exceeds the agricultural income, the farmer's willingness for farmland transfer changes significantly [16].

\subsection{Data Source and Sample Characteristics}

The data used in this study was derived from a questionnaire survey of 380 villages in 10 counties of the Anhui Province. The survey was conducted during the 2017 winter vacation. In terms of regions, 10 representative counties are selected according to the principle of similar economic development and population size. The specific distribution of the village area is shown in Table 1. For the villages' survey, this study selected 380 second- and third-grade students of the School of Economics and Management of An-Qing Normal University as investigators. The survey was mainly administered to the village head or secretary in the village. A total of 380 questionnaires were distributed, of which 326 were collected. There were 284 valid responses, and the overall efficiency of the questionnaire reached $87 \%$.

\section{Empirical Results and Explanation}

In order to explore the impact of improvements in rural road infrastructures on farmland transfer, this study employs a Tobit truncated regression analysis and adopts a regression strategy which is from simple to complex. The variables representing rural roads are first added in Model 1: several variables such as whether the village builds a road, whether the village has a national road, the distance to the provincial road, and distance between villages. In Model 2, two variables for village land rent and village per capita arable land area are added. In Model 3, the opportunity cost of non-agricultural production and the village agricultural production of village labor is also considered. Finally, in Models 4 to 6 , in order to avoid multi-collinearity problems between the three variables for the type of cultivated land in the village (mountain, hill, or plain), their effect on farmland transfer is analyzed by adding one or two variables at a time. The results are shown in Table 2 .

In Table 2, the impact of the core explanatory variable of the length of roads between villages on the farmland transfer rate is positive and significant at the $10 \%$ level. This means that for every $1 \%$ improvement in rural road infrastructures, the farmland transfer rate increases by 2.01 , showing that the improvement of rural road infrastructures can significantly promote the circulation of agricultural land. In terms of type of farmland transfer, the study found that the impact of hills and plains on the farmland transfer rate is positive and significant at the level of $10 \%$. The impact of mountainous type arable land is negative. This shows that the more barren, the harder the arable land in a natural state. Moreover, this result confirms the research conclusions by Wang X (2013) that poor physical and geographical conditions, low land output efficiency, and fragmented land severely restrict the scale of land transfer while increasing the transaction cost of circulation, thus creating a situation of supply shortage [17]. 
Table 1. Regional distribution, village number, and percentage of sample villages.

\begin{tabular}{cccc}
\hline \multirow{2}{*}{$\begin{array}{c}\text { Distribution area of } \\
\text { the sample village }\end{array}$} & Sample county & \multicolumn{2}{c}{ Overall sample } \\
\cline { 3 - 4 } West Anhui & Huoqiu County & 30 & Percentage rate \\
& Jinzhai County & 24 & $11 \%$ \\
\multirow{2}{*}{ Middle Anhui } & Feixi County & 27 & $8 \%$ \\
& Changfeng County & 28 & $10 \%$ \\
North Anhui & Shou County & 21 & $10 \%$ \\
& Xiao County & 20 & $7 \%$ \\
Southwest Anhui & Huai Ning County & 50 & $7 \%$ \\
& Zongyang County & 42 & $18 \%$ \\
& Guangde County & 23 & $8 \%$ \\
South Anhui & Xuanzhou District & 19 & $7 \%$ \\
& Total & 284 & 100 \\
\hline
\end{tabular}

Table 2. Tobit regression model results.

\begin{tabular}{|c|c|c|c|c|c|c|}
\hline \multirow{2}{*}{$\begin{array}{l}\text { Explained variable } \\
\text { Explaining variable }\end{array}$} & \multicolumn{6}{|c|}{ Farmland transfer rate } \\
\hline & Model 1 & Model 2 & Model 3 & Model 4 & Model 5 & Model 6 \\
\hline $\begin{array}{c}\text { Does the village build a } \\
\text { village road? }\end{array}$ & 10.86 & 10.41 & 10.61 & 12.58 & 11.83 & 11.83 \\
\hline $\begin{array}{c}\text { Does the village have a } \\
\text { national road and aprovincial } \\
\text { road nearby? }\end{array}$ & -3.28 & -1.56 & -1.37 & -2.41 & -2.46 & -2.46 \\
\hline $\begin{array}{l}\text { How long is the road } \\
\text { between villages? }\end{array}$ & 2.75 & $1.98^{\star}$ & $1.94^{*}$ & 2.13 & $2.01^{*}$ & $2.01^{\star}$ \\
\hline Village land rent & - & $0.05^{\star \star *}$ & $0.05^{\star * *}$ & $0.05^{\star * *}$ & $0.05^{\star * *}$ & $0.05^{\star * *}$ \\
\hline $\begin{array}{l}\text { Village per capita arable land } \\
\text { area }\end{array}$ & - & -6.25 & -0.73 & -0.43 & -0.47 & -0.47 \\
\hline $\begin{array}{l}\text { Non-agricultural production } \\
\text { status of village labor }\end{array}$ & - & - & 0.03 & 0.04 & 0.06 & 0.05 \\
\hline $\begin{array}{l}\text { Opportunity cost of village } \\
\text { agricultural production }\end{array}$ & - & - & -0.01 & -0.02 & -0.015 & -0.02 \\
\hline mountainous cultivated land & - & - & - & $-9.22^{*}$ & $-13.24^{*}$ & - \\
\hline $\begin{array}{c}\text { Is the type of cultivated land } \\
\text { in the village hilly? }\end{array}$ & - & - & - & - & 4.64 & $8.60^{*}$ \\
\hline $\begin{array}{c}\text { Is the type of cultivated land } \\
\text { in the village plain? }\end{array}$ & - & - & - & - & - & $13.24^{*}$ \\
\hline $\operatorname{LRChi} 2\left(\mathrm{X}_{\mathrm{i}}\right)$ & 4.94 & 44.48 & 44.76 & 48.23 & 48.85 & 48.85 \\
\hline Prob $>$ chi 2 & 0.1765 & 0.0000 & 0.0000 & 0.0000 & 0.0000 & 0.0000 \\
\hline Pseudo $\mathrm{R}^{2}$ & 0.0038 & 0.0344 & 0.0346 & 0.0373 & 0.0378 & 0.0378 \\
\hline Log Likelihood & -643.558 & -623.787 & -623.649 & -621.910 & -621.6029 & -621.603 \\
\hline
\end{tabular}

Note: ${ }^{*} \mathrm{P}<0.05,{ }^{* *} \mathrm{P}<0.01,{ }^{* * *} \mathrm{P}<0.001$. 


\section{Further Discussion and Robustness Analysis}

In order to verify the robustness of the results, the OLS estimation results are also shown. Since the value range of the interpreted variable is limited to the interval $[0,1]$, the explained variables should be transformed accordingly, making their value range between $( \pm \infty)$. The specific conversion approaches are as follows:

First assume that

$$
Y^{\prime}=\ln \frac{Y}{1-Y} .
$$

In formula (2), since the value range of $Y$ is between $[0,1]$, and $1 / Y(1-Y)>0$ is between $(0,+\infty)$, the value range of $Y$ becomes $( \pm \infty)$, the measurement model this time becomes:

$$
Y_{t}^{\prime}=\alpha+\beta X_{t}+\mu_{t} t=1,2,3, \cdots
$$

In formula (3), if $\beta>0$, then

$$
\beta=\frac{\partial Y^{\prime}}{\partial X}>0 \Rightarrow \frac{\partial[\ln Y-\ln (1-Y)]}{\partial X}>0
$$

Formula (4) is further simplified to obtain

$$
\frac{1}{Y} \frac{\partial Y}{\partial X}+\frac{1}{1-Y} \frac{\partial Y}{\partial X}>0 \Rightarrow \frac{1}{Y(1-Y)} \frac{\partial Y}{\partial X}>0
$$

In formula (5), since the value of $Y$ is in the range $[0,1]$, if $1 / Y(1-Y)>0$, then $\partial Y / \partial X>0$. Then, there is a positive relationship between the explaining variable and the explained interpreted variable $Y$. Therefore, in this study, the judgment over the $\beta$ coefficient is taken as the main method to check whether the measurement result is robust. According to the above analysis, in the first stage, the restricted explaining variables are transformed. Then, the traditional OLS test method is used to test the sub-samples separately [18]. The specific test results are shown in the following table (Table 3 ):

From Table 3, we can see that the length of roads also has a positive and significant effect on farmland transfer rate, which is consistent with the result of Tobit model regression, so the conclusions in this paper are verified.

\section{Research Conclusions}

In this paper, the impact of improvements in rural road infrastructures on farmland transfer is comprehensively examined from the perspective of agricultural production costs. The reference to a theoretical analysis is taken to discuss the final impact of the improvement in rural road infrastructures on the village farmland transfer.

The research contributions of this paper are as follows. First, the research on the willingness to transfer farmland only from the farmer perspective would lead to biased conclusions. Farmland transfer is the result of the joint efforts of both parties, an aspect that previous studies have not paid attention to. Second, there 
Table 3. The regression results of ols model.

\begin{tabular}{|c|c|c|c|}
\hline Explained variable & & and transfer & \\
\hline Explaining variable & Model 7 & Model 8 & Model 9 \\
\hline Does the village build a village road? & 0.70 & 0.67 & 0.68 \\
\hline $\begin{array}{l}\text { Does the village have a national road } \\
\text { and a provincial road nearby? }\end{array}$ & $-0.46^{\star *}$ & $-0.47^{\star \star}$ & $-0.47^{* *}$ \\
\hline $\begin{array}{c}\text { How long is the road between } \\
\text { villages? }\end{array}$ & $0.15^{* * *}$ & $0.14^{* * *}$ & $0.14^{* * *}$ \\
\hline Village land rent & $0.0004^{* * *}$ & $0.0004^{* * *}$ & $0.0003^{* * *}$ \\
\hline Village per capita arable land area & 0.06 & 0.058 & 0.058 \\
\hline $\begin{array}{l}\text { Non-agricultural production status } \\
\text { of village labor }\end{array}$ & 0.007 & 0.007 & 0.007 \\
\hline $\begin{array}{l}\text { Opportunity cost of village } \\
\text { agricultural production }\end{array}$ & -0.002 & -0.002 & -0.002 \\
\hline $\begin{array}{c}\text { Is the type of cultivated land in the } \\
\text { village mountainous? }\end{array}$ & $-0.54^{*}$ & -0.625 & - - \\
\hline $\begin{array}{c}\text { Is the type of cultivated land in the } \\
\text { village hilly? }\end{array}$ & -- & 0.092 & $0.533^{*}$ \\
\hline $\begin{array}{c}\text { Is the type of cultivated land in the } \\
\text { village plain? }\end{array}$ & - - & - - & 0.62 \\
\hline $\mathrm{R}^{2}$ & 0.35 & 0.40 & 0.39 \\
\hline F value & $2.10^{* *}$ & $3.22^{\star *}$ & $2.85^{*}$ \\
\hline
\end{tabular}

Notes: ${ }^{* *},{ }^{* *},{ }^{*}$ indicate the level of significance at $1 \%, 5 \%$, and $10 \%$, respectively.

is a lack of discussion on rural road infrastructure factors in the existing literature as a factor influencing farmland transfer. Improvements in the rural road infrastructure can significantly reduce the cost of agricultural production. In the end, it finally affects the behavioral decisions that determine land supply and demand, and then the circulation of agricultural land. The existing research has not yet addressed this issue.

The limitations of this study are mainly as follows. First, the village survey data is only limited to the Anhui Province, without other village survey data near the major agricultural provinces, which reduces the generalizability of the conclusions of this study. Second, the data used in this paper is mainly cross-sectional data, while the improvement in rural road infrastructures involves a long-term development and accumulation process, which is especially true for farmland transfer. Therefore, in order to increase the explanatory power of this study, panel data should be adopted in future research. Third, due to the limitations of the survey sample data, the rural road infrastructure in this study is mainly measured by the mileage of the village road. However, the rural road infrastructure variably entails different dimensions. For example, the division by the dimensions farmland water conservancy and power facilities may have different effects on the research results. Therefore, other variables can be consi- 
dered in future studies to explore the relationship between agricultural infrastructure and farmland transfer.

In terms of policy implications, this study proposes to further increase the quantity and quality of rural road infrastructures, and focus on the construction and maintenance of rural roads that are relevant for agricultural production and management activities [19]. When promoting the non-agricultural employment of rural labor, the high cost "bottleneck" of agricultural production cost caused by imperfect transportation facilities is resolved. In order to ensure increased investments in transportation infrastructures, the government departments could increase the budgetary funds, and appropriately guide private capital [20].

\section{Conflicts of Interest}

The author declares no conflicts of interest regarding the publication of this paper.

\section{References}

[1] Abdulai, A., Owusu, V. and Goetz, R. (2011) Land Tenure Differences and Investment in Land Improvement Measures: Theoretical and Empirical Analyses. Journal of Development Economics, 96, 66-78. https://doi.org/10.1016/j.jdeveco.2010.08.002

[2] Bowlus, A.J. and Sicular, T. (2004) Moving toward Markets? Labor Allocation in Rural China. Journal of Development Economics, 71, 561-583. https://doi.org/10.1016/S0304-3878(03)00040-3

[3] Carletto, C., Savastano, S. and Zezza, A. (2013) Fact or Artifact: The Impact of Measurement Errors on the Farm Size-Productivity Relationship. Journal of Development Economics, 103, 254-261. https://doi.org/10.1016/j.jdeveco.2013.03.004

[4] Davis, J. and Lopezcarr, D. (2014) Migration, Remittances and Smallholder Decision-Making: Implications for Land Use and Livelihood Change in Central America. Land Use Policy, 36, 319-329. https://doi.org/10.1016/j.landusepol.2013.09.001

[5] Brauw, A.D. and Rozelle, S. (2008) Migration and Household Investment in Rural China. China Economic Review, 19, 320-335. https://doi.org/10.1016/j.chieco.2006.10.004

[6] Deininger, K. and Jin, S. (2009) Securing Property Rights in Transition. Journal of Economic Behavior \& Organization, 70, 22-38. https://doi.org/10.1016/j.jebo.2009.01.001

[7] Deininger, K., Jin, S., Xia, F., et al. (2014) Moving off the Farm: Land Institutions to Facilitate Structural Transformation and Agricultural Productivity Growth in China. World Development, 59, 505-520. https://doi.org/10.1016/j.worlddev.2013.10.009

[8] Harris, J.R. and Todaro, M.P. (1970) Migration, Unemployment and Development: A Two-Sector Analysis. American Economic Review, 60, 126-142.

[9] Hoken, H. (2013) Development of Land Rental Market and Its Effect on Household Farming in Rural China: An Empirical Study in Zhejiang Province. Ide Discussion Papers.

[10] Huang, J.K., Wu, Y.H., Rozelle, S., et al. (2010) Moving off the Farm and Intensifying Agricultural Production in Shandong: A Case Study of Rural Labor Market Linkages in China. Agricultural Economics, 40, 203-218. 
https://doi.org/10.1111/j.1574-0862.2009.00370.x

[11] Ji, Y. and Zhong, F. (2011) Machinery Investment Decision and Off-Farm Employment in Rural China. Leibniz Institute of Agricultural Development in Central and Eastern Europe (IAMO).

[12] Kung, J.K.S. (2000) Common Property Rights and Land Reallocations in Rural China: Evidence from a Village Survey. World Development, 28, 701-719. https://doi.org/10.1016/S0305-750X(99)00148-5

[13] Ning, M., Gong, J., Zheng, X., et al. (2016) Does New Rural Pension Scheme Decrease Elderly Labor Supply? Evidence from CHARLS. China Economic Review, 41, 315-330.

[14] Hua, Q. (2010) Rural-to-Urban Labor Migration, Household Livelihoods, and the Rural Environment in Chongqing Municipality, Southwest China. Human Ecology, 38, 675-690. https://doi.org/10.1007/s10745-010-9353-Z

[15] Hou, Y.Y., Mao, L.X., Chao-Sheng, L.I., et al. (2008) Spatiotemporal Variation Pattern of Vegetation's Net Primary Productivity in China. Chinese Journal of Ecology.

[16] Tan, S., Heerink, N., Kruseman, G., et al. (2008) Do Fragmented Landholdings Have Higher Production Costs? Evidence from Rice Farmers in Northeastern Jiangxi Province, P.R. China. China Economic Review, 19, 347-358. https://doi.org/10.1016/j.chieco.2007.07.001

[17] Wang, X. (2013) Different Roles of Land in Rural-Urban Migration: Evidence from China's Household Survey. China \& World Economy, 21, 107-126.

https://doi.org/10.1111/j.1749-124X.2013.12011.x

[18] Kung, J.K.-S. and Bai, Y. (2011) Induced Institutional Change or Transaction Costs? The Economic Logic of Land Reallocations in Chinese Agriculture. Journal of Development Studies, 47, 1510-1528. https://doi.org/10.1080/00220388.2010.506916

[19] Li, S. and Vendryes, T. (2018) Real Estate Activity, Democracy and Land Rights in Rural China. China Economic Review. https://doi.org/10.1016/j.chieco.2018.05.004

[20] Kennedy, J.J. (2010) Supply and Support for Grassroots Political Reform in Rural China. Journal of Chinese Political Science, 15, 169-190.

https://doi.org/10.1007/s11366-010-9096-0 